\title{
Inventory of real world data sources in Parkinson's disease
}

\author{
Audrey Tanguy, Linus Jönsson and Lianna Ishihara*
}

\begin{abstract}
Background: Real world data have an important role to play in the evaluation of epidemiology and burden of disease; and in assisting health-care decision-makers, especially related to coverage and payment decisions. However, there is currently no overview of the existing longitudinal real world data sources in Parkinson's disease (PD) in the USA. Such an assessment can be very helpful, to support a future effort to harmonize real world data collection and use the available resources in an optimal way.

Methods: The objective of this comprehensive literature review is to systematically identify and describe the longitudinal, real world data sources in PD in the USA, and to provide a summary of their measurements (categorized into 8 main dimensions: motor and neurological functions, cognition, psychiatry, activities of daily living, sleep, quality of life, autonomic symptoms and other). The literature search was performed using MEDLINE, EMBASE and internet key word search.

Results: Of the 53 data sources identified between May and August 2016, 16 were still ongoing. Current medications (81\%) and comorbidities (79\%) were frequently collected, in comparison to medical imaging (36\%), genetic information (30\%), caregiver burden (11\%) and healthcare costs (2\%). Many different measurements $(n=108)$ were performed and an interesting variability among used measurements was revealed.

Conclusions: Many longitudinal real world data sources on PD exist. Different types of measurements have been performed over time. To allow comparison and pooling of these multiple data sources, it will be essential to harmonize practices in terms of types of measurements.
\end{abstract}

Keywords: Parkinson disease, Rating scales, Longitudinal, Cohort studies, Real-world

\section{Background}

Parkinson's disease (PD) is a progressive neurodegenerative disease affecting approximately 630,000 people in the USA and for which no disease-modifying therapy is currently available. With the ever growing ageing population, this number is projected to almost double to 1.1 million by 2030 [1].

The Food and Drug Administration (FDA) defines "real world data" as "all data collected from sources outside of traditional clinical trials" and "real world evidence" as "all evidence derived from aggregation and analysis of real world data" [2]. Such real world evidence reflecting disease progression, treatments and outcomes under conditions of routine clinical practice is a very

* Correspondence: liannaish@yahoo.com

Lundbeck SAS, 37-45 Quai du Président Roosevelt, CEDEX 92445

Issy-les-Moulineaux, France important resource. It can take a pivotal role to improve the understanding of the underlying disease process [3], optimize currently available therapies and develop new treatment strategies [2, 4].

Although the burden of PD and the interest of real world data are well-known $[5,6]$, there has not been a literature review to present the overview of longitudinal, real world studies conducted in the USA on PD patients.

There is a need for a comprehensive review to create an integrated view and assist investigators and clinicians to optimize the measurements that best match with their objectives and the already existing data sources [4, 7]. Such an assessment can be very helpful, to support a future effort to harmonize real world data collection and use the available resources in an optimal way.

The objective of this comprehensive literature review is to systematically identify and describe the longitudinal, 
real world data sources in PD, and to provide a summary of the key characteristics and the measurements assessed in real world studies, as a part of an effort to mobilize a harmonization process, similar to the one that already takes place in Europe.

\section{Methods}

\section{Search strategy and literature sources}

The search was performed on ProQuest. It was based in MEDLINE on Pubmed, in EMBASE and internet key word search between May and August 2016. Related MeSH, EMTREE and key terms were combined. Articles from peer-reviewed journals, conference abstracts and reviews were screened (AT). The search equation terms are detailed in Appendix 1.

\section{Study screening and selection}

We included all studies including patients with a diagnosis of PD based on real world data. We restricted inclusion to only longitudinal, observational cohort studies and registries. The setting was restricted to the USA and the timing of publication in the last 10 years (2006-2016). Cohorts or registries without any publication in the last 10 years were considered as outdated. Exclusion criteria were based on population characteristics: Other diagnosis (e.g. Wolff-Parkinson-White disease or only Parkinsonian syndromes), autopsy data, and studies not focused on patients (e.g. focused on physicians). Moreover, studies without American patients or non-longitudinal studies, such as case-control, were also excluded. Only one main exclusion criterion was reported in the flow chart per excluded study (Fig. 1). No limits were applied for language.

\section{Data extraction}

In a first step, when a publication allowed the identification of a data source of interest, the detailed information available in the publication was extracted. Information on design and setting, funding, population selection, follow-up and measurements were recorded. This was supplemented and updated via information found with an internet search of the study website, registration sites such as clinicaltrials.gov and investigators / funders' websites. The list of all information captured is available in Appendix 2.

In a second step, a classification of measurements was performed for the following dimensions: motor and neurological function, cognition, psychiatric symptoms, activities of daily living, sleep quality, quality of life, autonomic symptoms and other. The "other" dimension gathers some known PD symptoms such as olfaction [8] not included in the previous main dimensions and more general information such as caregivers' burden measurements. Some dimensions were subdivided in sub dimensions due to their complexity and variety (e.g. Motor and neurological symptoms is sub divided into $4 \mathrm{sub}$ dimensions: global, gait and balance, fine movement and

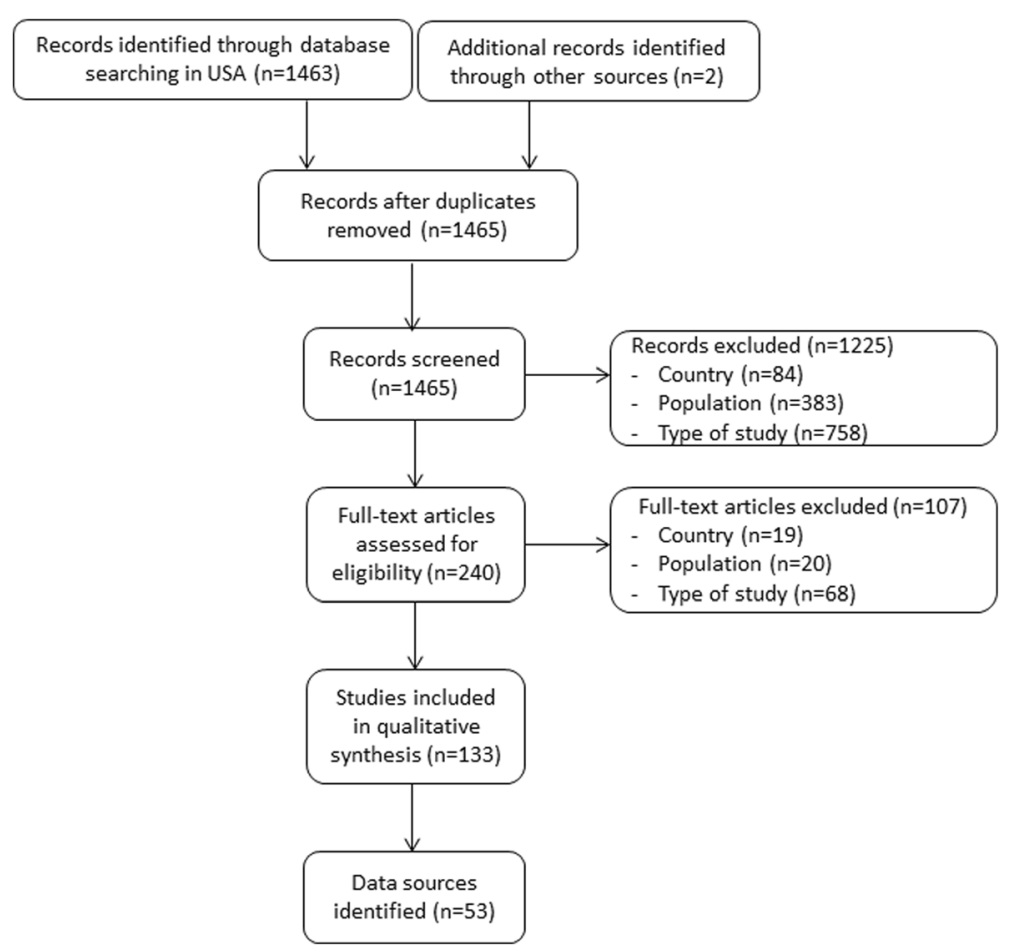

Fig. 1 Flowchart 
other). This classification was based on the literature [4] with one adaptation: as very few sensory markers were identified, they were gathered in the "other" category.

\section{Data analysis}

Data source characteristics were described globally. To address the variability of sources, the description was also performed according to four main characteristics: the completion status (ongoing vs completed); the study population (Parkinson specific data sources vs "generic" data sources including both Parkinsonian patients and patients of other diagnostics); the categories of studies (investigate for motor symptoms, non-motor symptoms, biomarkers, genetics or mixed); and the country (US only vs international sources). Descriptive statistics were reported as absolute frequency and percentages.

\section{Results}

Of 1463 records screened, 84\% were excluded based on title and abstract, and 7\% after review of the full-text
(Fig. 1). The most frequent exclusion criterion was that studies were not longitudinal. Only 133 (9\%) were included in the qualitative analysis. Of these 133 studies, data from 53 different data sources were extracted [9$61]$. Only one registry was included with 52 cohorts.

\section{Longitudinal real world sources (Table 1)}

Forty-two sources (79\%) were only in the USA. Three of the 11 international sources were only in North America while the other eight included patients in the USA and Europe, and two also included Asia. Most of the sources included less than 500 PD patients (79\%) for more than 5 years (51\%). Although most of the sources included information about current medications (81\%) and comorbidities (79\%); only few collected information on medical imaging (36\%), genetics (30\%), caregiver' burden (11\%) and healthcare costs (2\%).

Among the 53 sources, 16 (30\%) are still ongoing. There has been an increased availability of genetic information ( $38 \%$ vs $27 \%)$ and caregivers' burden data ( $27 \%$ vs $5 \%$ ) in ongoing versus completed sources, respectively. Moreover,

Table 1 Overview of data sources characteristics $(n=53)$

\begin{tabular}{|c|c|c|c|c|c|c|c|}
\hline \multirow[t]{2}{*}{ Characteristics } & \multirow{2}{*}{$\begin{array}{l}\text { Included } \\
\text { All }(n=53)\end{array}$} & \multicolumn{2}{|l|}{ Status } & \multicolumn{2}{|l|}{ Country } & \multicolumn{2}{|l|}{ Study population } \\
\hline & & Ongoing $(n=16)$ & Completed $(n=37)$ & USA $(n=42)$ & International $(n=11)$ & $\begin{array}{l}\text { Parkinson cohort } \\
(n=25)\end{array}$ & $\begin{array}{l}\text { "Generic" cohort } \\
(n=28)\end{array}$ \\
\hline \multicolumn{8}{|c|}{ Size (number of Parkinsonian patients) } \\
\hline $0-500$ & $42(79)$ & $11(69)$ & $31(84)$ & $37(88)$ & $5(45)$ & $22(88)$ & $20(71)$ \\
\hline $500-1000$ & $7(13)$ & $4(25)$ & $3(8)$ & $3(7)$ & $4(36)$ & $3(12)$ & $4(14)$ \\
\hline$>1000$ & $4(8)$ & $1(6)$ & $3(8)$ & $2(5)$ & $2(18)$ & $0(0)$ & $4(14)$ \\
\hline \multicolumn{8}{|l|}{ Duration of follow-up (years) } \\
\hline$<2$ & $6(11)$ & $0(0)$ & $6(16)$ & $4(10)$ & $2(18)$ & $4(16)$ & $2(7)$ \\
\hline $2-5$ & $20(38)$ & $4(25)$ & $16(43)$ & $16(38)$ & $4(36)$ & $13(52)$ & $7(25)$ \\
\hline$\geq 5$ & $27(51)$ & $12(75)$ & $15(41)$ & $22(52)$ & $5(45)$ & $8(32)$ & $19(68)$ \\
\hline \multicolumn{8}{|l|}{ Dimensions assessed } \\
\hline Motor and neurological & $46(87)$ & $12(75)$ & $34(92)$ & $36(86)$ & $10(91)$ & $25(100)$ & $21(75)$ \\
\hline Cognition & $41(77)$ & $13(81)$ & $28(76)$ & $36(86)$ & $5(45)$ & $17(68)$ & $24(86)$ \\
\hline Psychiatric symptoms & $38(72)$ & $10(63)$ & $28(76)$ & $30(71)$ & $8(73)$ & $19(76)$ & $17(61)$ \\
\hline Activities of daily living & $22(42)$ & $6(38)$ & $16(43)$ & $15(36)$ & $7(64)$ & $12(48)$ & $10(36)$ \\
\hline Sleep quality & $11(21)$ & $4(25)$ & $7(19)$ & $5(12)$ & $6(55)$ & $2(8)$ & $9(32)$ \\
\hline Quality of life & $9(17)$ & $4(25)$ & $5(14)$ & $5(12)$ & $4(36)$ & $6(24)$ & $3(11)$ \\
\hline Autonomic symptoms & $7(13)$ & $4(25)$ & $3(8)$ & $3(7)$ & $4(36)$ & $0(0)$ & $7(25)$ \\
\hline Other & $20(38)$ & $9(56)$ & $11(30)$ & $13(31)$ & $7(64)$ & $8(32)$ & $12(43)$ \\
\hline \multicolumn{8}{|l|}{ Other assessments } \\
\hline Current medications & $43(81)$ & $13(81)$ & $30(81)$ & $32(76)$ & $11(100)$ & $22(88)$ & $21(75)$ \\
\hline Comorbidities & $42(79)$ & $14(88)$ & $28(76)$ & $31(74)$ & $11(100)$ & $20(80)$ & $22(79)$ \\
\hline Medical imaging & $19(36)$ & $6(40)$ & $13(34)$ & $11(26)$ & $8(73)$ & $6(24)$ & $13(46)$ \\
\hline Genetics & $16(30)$ & $6(38)$ & $10(27)$ & $10(24)$ & $6(55)$ & $3(12)$ & $13(46)$ \\
\hline Caregiver burden & $6(11)$ & $4(27)$ & $2(5)$ & $5(12)$ & $1(9)$ & $4(16)$ & $2(7)$ \\
\hline Healthcare costs & $1(2)$ & $1(7)$ & $0(0)$ & $0(0)$ & $1(9)$ & $1(4)$ & $0(0)$ \\
\hline
\end{tabular}

Data are shown as absolute frequency (percentage) 
there has been a trend toward larger inclusions and longer durations: comparing ongoing versus completed sources, $31 \%$ vs $16 \%$ included more than 500 patients and $75 \%$ vs $41 \%$ have a duration of more than 5 years.

Likewise, US sources were smaller and shorter than international sources ( $88 \%$ vs $45 \%$ included less than 500 PD patients, and $52 \%$ vs $45 \%$ have a duration of more than 5 years). US sources reported more caregiver burden data than international sources (12\% vs $9 \%$ ) but less frequently the other assessments such as medical imaging (26\% vs $73 \%$ ) or genetic information (24\% vs $55 \%$ ).

Sources including only Parkinsonian patients were smaller ( $12 \%$ vs $28 \%$ included more than 500 patients) and shorter (32\% vs $68 \%$ had a duration of more than 5 years) than the "generic" cohorts. Medical imaging (24\% vs $46 \%)$ and genetics ( $12 \%$ vs $46 \%)$ were less assessed in Parkinson's specific than in "generic" cohorts.

The 53 data sources have different objectives. Mainly the sources investigated as their primary objective: nonmotor symptoms (32\%), then biomarkers (21\%), motor symptoms (15\%) and genetics (4\%). Fifteen sources (28\%) investigated several of these points as first objective. The sources investigating the biomarkers as primary objective were large and recent with four sources still ongoing and four sources begun in the last 5 years. In contrast, the sources investigating the motor symptoms as primary objective were small, all with less than 500 patients and with very frequent assessment, on average twice a year.

\section{Measurements in real world studies in PD}

The name of each included data source with its main characteristics (Table 2) and its measurements (Table 3) are presented individually. A large number of measurements $(n=108)$ was identified through this literature review and each of the 53 sources had its own unique range of measurements (Table 4). Most of the measurements were cited only once or twice. The distribution of the number of measurements over the different dimensions was not equal with only 3 different to assess autonomic symptoms and 43 to assess cognition.

Most sources assessed motor and neurological functions (87\%), cognition (77\%) and psychiatric symptoms (72\%). Activity level (42\%), sleep quality (21\%), quality of life (17\%) and autonomic symptoms (13\%) were reported to a lesser extent. The most commonly measurements used to assess motor and neurological symptoms were the Unified Parkinson's Disease Rating Scale part III (UPDRS-III, 77\% of included data sources) and the Hoehn and Yahr scale (H\&Y, $57 \%$ of included data sources)(Table 4). To evaluate the cognitive impairment, the Mini Mental State Examination (MMSE, 57\%) was the most frequent. Those most frequently used to assess psychiatric symptoms were the Geriatric Depression Scale (GDS, 32\%) and Beck Depression
Inventory (BDI, 15\%). For the other dimensions, the most commonly used measurements were: the Epworth Sleepiness Scale (ESS, 8\%, for sleep), the Schwab and England (S\&E, 19\%, for activities of daily living), the 39item Parkinson's disease Quality of life (PDQ-39, 9\%, for the quality of life) and the autonomic part of the Scales for outcomes of Parkinson's disease (SCOPA-AUT, 6\%, for autonomic symptoms). In absolute frequency, the use of ESS, PDQ-39 and SCOPA-AUT is very low, even if they were the most frequently used measurements in their dimension.

The analysis reveals some interesting differences between sources on the number of measurements applied by dimension. Some sources evaluate only one dimension (source $n^{\circ}$ 13) when others evaluate seven dimensions (source $n^{\circ} 43$ ). Completed sources have more frequent measurements of motor and neurological symptoms (92\% vs $75 \%$ ), psychiatric symptoms ( $76 \%$ vs $63 \%$ ) and activities of daily living (43\% vs $38 \%$ ) than ongoing sources. US sources evaluate more frequently the cognitive impairment then international sources ( $86 \%$ vs $45 \%$ ) but less frequently all the other dimensions. "Generic" sources evaluate three dimensions more frequently than specific sources including only Parkinsonian patients: cognition ( $86 \%$ vs $68 \%)$, sleep (32\% vs $8 \%$ ) and autonomic symptoms ( $25 \%$ vs $0 \%$ ).

Lastly, the frequencies of these assessments are dependent on the primary objective of the sources but with an important overlap: 100\% of the sources investigating motor symptoms used measurements of motor symptoms and mainly the UPDRS-III, but they also frequently assessed cognition (88\%), sleep (25\%) and quality of life $(25 \%)$. The sources investigating non-motor symptoms frequently assessed cognition (82\%), psychiatric symptoms $(88 \%)$ most of the time with, respectively, the GDS (41\%) and the MMSE (65\%). The two genetic sources have several patient reported outcomes and they both measured motor and psychiatric symptoms.

Some measurements were used more often for some above-mentioned objectives. While the GDS and the UPDRS-III were used specifically in sources investigating, respectively, the non-motor symptoms and the motor symptoms as a primary objective, the BDI and the $\mathrm{H} \& \mathrm{Y}$ were used in sources investigating the other objectives.

\section{Discussion}

A large number of longitudinal real world data sources for PD have been identified. There is no consistency of the dimensions assessed, nor of the measurements used across sources, reflecting the absence of harmonization on the optimal choice of measurements.

There are a number of issues with collecting real world data such as limited size of the databases [1], inability to accurately determine specific outcomes [62], and more chance of bias and confounding factors [5]. 
Table 2 Overview of data sources characteristics listed in alphabetic order $(n=53)$

\begin{tabular}{|c|c|c|c|c|c|c|}
\hline $\mathrm{Nb}$ & Study & Acronym & $\begin{array}{l}\text { Individuals } \\
\text { included }\end{array}$ & $\begin{array}{l}\text { Follow- } \\
\text { up duration (y) }\end{array}$ & Planned follow-up & Main inclusion criteria \\
\hline 1 & $\begin{array}{l}\text { A Longitudinal Observational Follow-up of the } \\
\text { PRECEPT Study Cohort }{ }^{\mathrm{a}}\end{array}$ & PostCEPT & 537 & 4 & & $\begin{array}{l}\text { Post-RCT; under } \\
\text { dopaminergic therapy }\end{array}$ \\
\hline 2 & $\begin{array}{l}\text { Abnormalities in metabolic network activity } \\
\text { precede the onset of motor symptoms in } \\
\text { Parkinson's disease }\end{array}$ & & 15 & 4 & Every 2 years & Hemi parkinsonism \\
\hline 3 & $\begin{array}{l}\text { Amyloid is linked to cognitive decline in } \\
\text { patients with Parkinson disease without dementia }\end{array}$ & & 46 & 5 & Annually & \\
\hline 4 & $\begin{array}{l}\text { Arizona Study of Aging and Neurodegenerative } \\
\text { Disease }\end{array}$ & AZSAND & 3000 & ongoing & & \\
\hline 5 & Ashkenazi Jewish LRRK2 consortium cohort & LRRK2 & 2611 & 1.5 & Every $12-18$ months & Ashkenazi Jewish \\
\hline 6 & Baltimore Longitudinal Study of Aging & BLSA & $10,000 ?$ & ongoing & Every few years for life & Healthy \\
\hline 7 & $\begin{array}{l}\text { Boston university medical center - University of } \\
\text { Alabama Birmingham - Washington University } \\
\text { in Saint Louis School of medicine }\end{array}$ & & 80 & 2 & & $>40$ years \\
\hline 8 & Central Control of Mobility in Aging & CCMA & 439 & ongoing & Annually & $\begin{array}{l}\text { Elderly (>65 years); non } \\
\text { demented }\end{array}$ \\
\hline 9 & $\begin{array}{l}\text { Cerebral glucose metabolic features of Parkinson } \\
\text { disease and incident dementia: longitudinal study }\end{array}$ & & 50 & 4 & Annually & Levodopa treatment \\
\hline 10 & $\begin{array}{l}\text { Charting the progression of disability in } \\
\text { Parkinson disease }\end{array}$ & & 171 & 2 & Every 6 months & $\begin{array}{l}>40 \text { years; mild to } \\
\text { moderate Parkinson's } \\
\text { disease }\end{array}$ \\
\hline 11 & $\begin{array}{l}\text { Clinical course in Parkinson's disease with } \\
\text { elevated homocysteine }\end{array}$ & & 97 & 2 & Every 2 years & $\begin{array}{l}35-90 \text { years without brain } \\
\text { surgery or neurologic/ } \\
\text { psychiatric comorbidity }\end{array}$ \\
\hline 12 & $\begin{array}{l}\text { Clinical Research in Neurology (CRIN) - } \\
\text { Emory center }\end{array}$ & CRIN & 3581 & 15 & & \\
\hline 13 & $\begin{array}{l}\text { Comparative utility of the BESTest; mini-BESTest; } \\
\text { and brief-BESTest for predicting falls in } \\
\text { individuals with Parkinson disease: a cohort study }\end{array}$ & BESTest & 80 & 1 & Every 6 months & $\begin{array}{l}\text { Without neuropsychiatric } \\
\text { comorbidities }\end{array}$ \\
\hline 14 & $\begin{array}{l}\text { Comparison of the Agonist Pramipexole With } \\
\text { Levodopa on Motor Complications of } \\
\text { Parkinson's Disease }\end{array}$ & $\begin{array}{l}\text { CALM-PD } \\
\text { follow-up }\end{array}$ & 301 & 2 & Annually & $\begin{array}{l}\text { Post-RCT; under } \\
\text { dopaminergic therapy; } \\
\text { diagnostic }<7 \text { years }\end{array}$ \\
\hline 15 & Contursi kindred & CONTURSI & 210 & $?$ & & \\
\hline 16 & $\begin{array}{l}\text { Deprenyl and Tocopherol Antioxidative } \\
\text { Therapy of Parkinsonism }{ }^{\mathrm{a}}\end{array}$ & DATATOP & 403 & 6 & Every 3 months & $\begin{array}{l}\text { Early phase; postRCT; } \\
30-79 \text { years }\end{array}$ \\
\hline 17 & Depression in Parkinson's disease & & 685 & 3.9 & Annually & \\
\hline 18 & $\begin{array}{l}\text { Dopamine agonist withdrawal syndrome in } \\
\text { Parkinson disease }^{a}\end{array}$ & DAWS & 93 & 0.25 & Annually & Non demented \\
\hline 19 & Einstein Aging Study (Bronx Aging Study) & EAS & 791 & ongoing & Every 12 to 18 months & Elderly (>70 years) \\
\hline 20 & $\begin{array}{l}\text { Emergence and evolution of social self- } \\
\text { management of Parkinson's disease }\end{array}$ & & 120 & 3 & Every 6 months & Non demented \\
\hline 21 & $\begin{array}{l}\text { Hallucinations and sleep disorders in PD: } \\
\text { ten-year prospective longitudinal study }\end{array}$ & & 89 & 10 & $\begin{array}{l}0 ; 6 \text { months; } 18 \text { months; } \\
4 \text { years; } 6 \text { years; } \\
10 \text { years }\end{array}$ & $\begin{array}{l}\text { 24-h caregiver; without } \\
\text { neuroleptic treatment; } \\
\text { without some } \\
\text { comorbidities }\end{array}$ \\
\hline 22 & Harvard Alumni Health Study & & 500,002 & 77 & $\begin{array}{l}\text { 1962; 1966; 1972; 1988; } \\
1993\end{array}$ & Harvard students \\
\hline 23 & Health Professionals Follow-up Study & HPFS & 51,529 & ongoing & Biannually & Men; healthy; $40-75$ years \\
\hline 24 & Honolulu Asia Aging Study & HAAS & 3741 & 15 & $\begin{array}{l}3 \text { times } \\
\text { between } 1994 \text { and } 2001\end{array}$ & $\begin{array}{l}\text { Elderly Japanese- } \\
\text { American men }\end{array}$ \\
\hline 25 & $\begin{array}{l}\text { Longitudinal study of normal cognition in } \\
\text { Parkinson disease }\end{array}$ & & 141 & 6 & $\begin{array}{l}\text { Biannual for } 4 \text { years and } \\
\text { annual after }\end{array}$ & $\begin{array}{l}\text { Normal cognition at } \\
\text { baseline }\end{array}$ \\
\hline 26 & & & 33 & 2 & & \\
\hline
\end{tabular}


Table 2 Overview of data sources characteristics listed in alphabetic order $(n=53)$ (Continued)

\begin{tabular}{|c|c|c|c|c|c|c|}
\hline $\mathrm{Nb}$ & Study & Acronym & $\begin{array}{l}\text { Individuals } \\
\text { included }\end{array}$ & $\begin{array}{l}\text { Follow- } \\
\text { up duration (y) }\end{array}$ & Planned follow-up & Main inclusion criteria \\
\hline & $\begin{array}{l}\text { Long-term outcomes of bilateral subthalamic } \\
\text { nucleus stimulation in patients with advanced } \\
\text { Parkinson's disease }\end{array}$ & & & & $\begin{array}{l}0-3-6-12-18- \\
24 \text { months }\end{array}$ & $\begin{array}{l}\text { Advanced phase with } \\
\text { deep brain stimulation }\end{array}$ \\
\hline 27 & $\begin{array}{l}\text { Loss of ability to work and ability to live } \\
\text { independently in Parkinson's disease }\end{array}$ & & 495 & 10 & & \\
\hline 28 & $\begin{array}{l}\text { Major life events and development of major } \\
\text { depression in Parkinson's disease patients }\end{array}$ & PEG study & 221 & 4 & Annually & $\begin{array}{l}\text { New onset (within } \\
3 \text { years) }\end{array}$ \\
\hline 29 & $\begin{array}{l}\text { Mayo Clinic cohort study of Personality and } \\
\text { Aging (including Rochester Epidemiology } \\
\text { project) }\end{array}$ & & 7216 & 29.2 & Historically for life & 20-69 years \\
\hline 30 & $\begin{array}{l}\text { Mayo clinic study of aging (Olmsted county } \\
\text { resident) - Rochester Epidemiology project } \\
\text { indexing system }\end{array}$ & MCSA & 2739 & ongoing & & \\
\hline 31 & Molecular Epidemiology of Parkinson's Disease & MEPD & 1600 & ongoing & & $>40$ years \\
\hline 32 & $\begin{array}{l}\text { Mood and motor trajectories in Parkinson's } \\
\text { disease: multivariate latent growth curve } \\
\text { modeling }\end{array}$ & & 186 & 1.5 & 6 months; 18 months & \\
\hline 33 & $\begin{array}{l}\text { Mood and Subthalamic Nucleus Deep } \\
\text { Brain Stimulation }^{\mathrm{a}}\end{array}$ & MOST & 91 & 1 & & $\begin{array}{l}\text { Deep brain stimulation } \\
\text { eligible; not demented }\end{array}$ \\
\hline 34 & $\begin{array}{l}\text { Morris K Udall Parkinson's Disease Research } \\
\text { Center of Excellence cohort - Veteran affair }\end{array}$ & Udall & 314 & ongoing & & Elderly (>60 years) \\
\hline 35 & $\begin{array}{l}\text { National Parkinson Foundation Quality } \\
\text { Improvement Initiative }\end{array}$ & NPF-Q\|I & 10,000 & on going & & \\
\hline 36 & NeuroGenetics Research Consortium & NGRC & 3072 & $>10$ & & \\
\hline 37 & Nurses' Health Study & $\mathrm{NHS}$ & 280,000 & ongoing & Every 2 years & $\begin{array}{l}\text { Women; healthy; } \\
19-51 \text { years }\end{array}$ \\
\hline 38 & Oxford Parkinson's Disease Centre & OPDC & 1500 & 1.5 & 18 months & \\
\hline 39 & Parkinson's Associated Risk Study & PARS & 10,000 & ongoing & & Elderly (>60 years) \\
\hline 40 & Parkinson's Disease Biomarkers Program & PDBP & 1436 & ongoing & & $\begin{array}{l}\text { Evidence of response to } \\
\text { dopaminergic } \\
\text { medication }\end{array}$ \\
\hline 41 & $\begin{array}{l}\text { Parkinson's Disease Research Education and } \\
\text { Clinical Center - Parkinson's Genetic } \\
\text { Research Study }\end{array}$ & $\begin{array}{l}\text { PADRECCS } \\
\text { - PaGeR }\end{array}$ & 1880 & ongoing & & \\
\hline 42 & $\begin{array}{l}\text { Parkinson's disease: increased motor network } \\
\text { activity in the absence of movement }\end{array}$ & NMRP & 12 & 4.4 & Every 2 years & $\begin{array}{l}\text { Non demented; tremor- } \\
\text { dominant clinical mani } \\
\text { festations; without some } \\
\text { comorbidities }\end{array}$ \\
\hline 43 & Parkinson's Progression bioMarkers Initiative & PPMI & 748 & ongoing & $\begin{array}{l}\text { Every } 3 \text { months the first } \\
\text { year then every } \\
6 \text { months }\end{array}$ & $\begin{array}{l}\text { Untreated recently } \\
\text { diagnosed }\end{array}$ \\
\hline 44 & $\begin{array}{l}\text { Prospective cohort study of impulse control } \\
\text { disorders in Parkinson's disease }\end{array}$ & ICD-PD & 164 & 4 & & Non demented \\
\hline 45 & $\begin{array}{l}\text { Rate of 6-18Ffluorodopa uptake decline in striatal } \\
\text { subregions in Parkinson's disease }\end{array}$ & & 37 & 4 & Every 1 to 2 years & \\
\hline 46 & Religious Order Study & ROS & $>1100$ & $>7$ & Annually & Elderly; religious clergy \\
\hline 47 & Rush Memory and Aging Project & RMAP & 1556 & 5 & Annually & $\begin{array}{l}\text { Elderly without know } \\
\text { dementia }\end{array}$ \\
\hline 48 & $\begin{array}{l}\text { Study of Osteoporotic Fractures (SOF) } \\
\text { Research Group }\end{array}$ & SOF & 9704 & $>6$ & Tri-annually & $\begin{array}{l}\text { Women; Elderly } \\
\text { ( }>65 \text { years })\end{array}$ \\
\hline 49 & $\begin{array}{l}\text { The effect of age of onset of PD on risk } \\
\text { of dementia }\end{array}$ & & 440 & 4 & Annually & Elderly (>65 years) \\
\hline 50 & $\begin{array}{l}\text { University of California Los Angeles Center for } \\
\text { Genes and Environmental in Parkinson's Disease }\end{array}$ & $\begin{array}{l}\text { UCLA } \\
\text { CGEP }\end{array}$ & 363 & 5 & & Diagnostic $>3$ years \\
\hline
\end{tabular}


Table 2 Overview of data sources characteristics listed in alphabetic order $(n=53)$ (Continued)

\begin{tabular}{lllllll}
\hline Nb & Study & Acronym & $\begin{array}{l}\text { Individuals } \\
\text { included }\end{array}$ & $\begin{array}{l}\text { Follow- } \\
\text { up duration (y) }\end{array}$ & Planned follow-up & Main inclusion criteria \\
\hline 51 & University of Miami Brain Endowment Bank & UM/BEB & 150 & ongoing & Annually & Consent to donate brain \\
52 & $\begin{array}{l}\text { UPDRS activity of daily living score as a marker } \\
\text { Of Parkinson's disease progression }\end{array}$ & 162 & 6 & Every 2 years & \\
53 & Washington Heights-Inwood Columbia Aging & WHICAP & 2776 & 3.7 & Annually & Elderly (>65 years) \\
\hline
\end{tabular}

Post-RCT = Open label extension after a Randomized Controlled Trial

${ }^{\mathrm{a}}$ Treatment directed data sources

Nevertheless, they have an important role to play in the evaluation of epidemiology, burden of disease and treatments patterns [6]; and in assisting health-care decision-makers, especially related to coverage and payment decisions [63]. In this context, a harmonization seems necessary. These results are quite consistent with those observed in Europe where a "consensus on domains incorporated in different studies [was observed] with a substantial variability in the choice of the evaluation method" [4]. There are a number of possible explanations for this absence of harmonization and some of them are discussed here.

First of all, some dimensions are broad. In consequence many measurements are available according to each source objective, design and population. This heterogeneity probably reflects both the absence of harmonization and the complexity of the evaluation of a dimension like cognition [64]. A single measurement cannot assess all necessary information. For example, the combination of patient reported outcomes and medical reported outcomes can be very informative and complement one another. In a consistent manner, the combination of Parkinson specific and generic measurements can be a necessity especially for "generic" data sources including not only Parkinsonian patients. In another example, while the objectives of the UPDRS-III and the H\&Y (or of the GDS and the BDI) are close, the difference of their use according to the study primary objective of the source seems more linked to the investigator choice than to the suitability of the measurement.

Secondly, PD is characterized by several initial system disorders and treatment complications [65]. To date, motor subtyping has dominated the landscape of PD research but non-motor dimensions evaluations are increasing $[9,66]$, and thus the number of dimensions to evaluate. For non-motor dimensions, some have validated measurements such as psychiatry [67], activity disability [7], sleep [68] or quality of life [69]; but others have no clear review of validated and used scales [4]. Among the psychiatric scales, the two most frequently used were the GDS and the BDI. This finding highlights the well-known relationship between PD and depression, and the fact that when validated scales [70] are available, a harmonization of practice is observed. The lack of evaluation and validation of the measurements in PD is probably partly a source of such an heterogeneity.

Thirdly, clinical research purposes and outcomes are in permanent evolution over time [71, 72], as highlighted by the many differences between completed and ongoing sources. New trends are not well covered right now, either due to lack of measurements or due to lack of capture (i.e. utilization of available measurements in databases). Among the most important of those are the genetic testing, the caregiver burden and the costs. The important development of genetic testing has come in the last few years, with an increase of the mutations and treatment discoveries such as LRRK2 and its kinase inhibitors. But research is necessary to understand the role of genetic mutations in PD [73]. Sources based on caregiver burden and relevant validated measurements are very limited [7]. But the interest for these data is growing with the recognition of their physical, emotional and economic burden [74]. The only data source identified as measuring healthcare costs associated with $\mathrm{PD}$ was ongoing. It probably reflects both the recent growing interest of health economic evaluation and the fact that this type of study is more often conducted in automated healthcare databases [75].

Fourthly, there is a possible improvement of the access to the data source details. Given information is fragmented between different sources of information and study protocols or outcomes lists are not always available. In consequence identifying and gathering this information to produce an integrated view can be really difficult.

Finally, the variability of our results is greater than in the European study. This may be because the classification is based on dimensions assessing mostly symptoms, 5 out of 8 dimensions. This classification probably more appropriate for data sources with a primary objective of treatment evaluation (e.g. open-label extension), which are a minority of the included sources. The classification may not be as applicable to assess other data sources focused on the evaluation of burden. Real world evidence collection is done for various purposes and such a restricted classification can lead to ambiguous conclusions. It can lead to a perception of consensus while actually missing important aspects such as burden, function or complications of treatments. 
Table 3 Overview of data source measurements and of the number of evaluations or assessments applied $(n=53)$

\begin{tabular}{|c|c|c|c|c|c|c|c|c|c|}
\hline $\mathrm{Nb}$ & Study & $\begin{array}{l}\text { Motor and } \\
\text { neurological }\end{array}$ & Cognition & Psychiatry & $\begin{array}{l}\text { Activities } \\
\text { of daily living }\end{array}$ & Sleep & $\begin{array}{l}\text { Quality } \\
\text { of life }\end{array}$ & Autonomic & Other \\
\hline 1 & $\begin{array}{l}\text { A Longitudinal Observational Follow-up of the PRECEPT } \\
\text { Study Cohort }\end{array}$ & 3 & 4 & 3 & 1 & 0 & 0 & 0 & 0 \\
\hline 2 & $\begin{array}{l}\text { Abnormalities in metabolic network activity precede } \\
\text { the onset of motor symptoms in Parkinson's disease }\end{array}$ & 2 & 0 & 0 & 0 & 0 & 0 & 0 & 0 \\
\hline 3 & $\begin{array}{l}\text { Amyloid is linked to cognitive decline in patients with } \\
\text { Parkinson disease without dementia }\end{array}$ & 2 & 14 & 1 & 0 & 0 & 0 & 0 & 0 \\
\hline 4 & Arizona Study of Aging and Neurodegenerative Disease & 4 & 12 & 3 & 0 & 1 & 0 & 1 & 1 \\
\hline 5 & Ashkenazi Jewish LRRK2 consortium cohort & 3 & 2 & 2 & 2 & 1 & 0 & 1 & 1 \\
\hline 6 & Baltimore Longitudinal Study of Aging & 0 & 2 & 3 & 0 & 0 & 0 & 0 & 0 \\
\hline 7 & $\begin{array}{l}\text { Boston university medical center - University of } \\
\text { Alabama Birmingham - Washington University in } \\
\text { Saint Louis School of medicine }\end{array}$ & 9 & 1 & 1 & 0 & 0 & 1 & 0 & 0 \\
\hline 8 & Central Control of Mobility in Aging & 2 & 1 & 1 & 0 & 0 & 0 & 0 & 0 \\
\hline 9 & $\begin{array}{l}\text { Cerebral glucose metabolic features of Parkinson } \\
\text { disease and incident dementia: longitudinal study }\end{array}$ & 1 & 6 & 0 & 0 & 0 & 0 & 0 & 0 \\
\hline 10 & $\begin{array}{l}\text { Charting the progression of disability in } \\
\text { parkinson disease }\end{array}$ & 9 & 1 & 1 & 0 & 0 & 1 & 0 & 0 \\
\hline 11 & $\begin{array}{l}\text { Clinical course in Parkinson's disease with } \\
\text { elevated homocysteine }\end{array}$ & 1 & 9 & 1 & 1 & 0 & 0 & 0 & 0 \\
\hline 12 & Clinical Research in Neurology (CRIN) - Emory center & 0 & 1 & 0 & 0 & 0 & 0 & 0 & 0 \\
\hline 13 & $\begin{array}{l}\text { Comparative utility of the BESTest; mini-BESTest; and } \\
\text { brief-BESTest for predicting falls in individuals with } \\
\text { Parkinson disease: a cohort study }\end{array}$ & 5 & 0 & 0 & 0 & 0 & 0 & 0 & 0 \\
\hline 14 & $\begin{array}{l}\text { Comparison of the Agonist Pramipexole With } \\
\text { Levodopa on Motor Complications of Parkinson's Disease }\end{array}$ & 3 & 1 & 2 & 2 & 1 & 3 & 0 & 0 \\
\hline 15 & Contursi kindred & 1 & 1 & 1 & 1 & 1 & 0 & 1 & 1 \\
\hline 16 & $\begin{array}{l}\text { Deprenyl and Tocopherol Antioxidative Therapy } \\
\text { of Parkinsonism }\end{array}$ & 2 & 5 & 0 & 0 & 0 & 0 & 0 & 0 \\
\hline 17 & Depression in Parkinson's disease & 2 & 0 & 1 & 1 & 0 & 0 & 0 & 0 \\
\hline 18 & $\begin{array}{l}\text { Dopamine agonist withdrawal syndrome in } \\
\text { parkinson disease }\end{array}$ & 2 & 1 & 4 & 1 & 0 & 1 & 0 & 0 \\
\hline 19 & Einstein Aging Study (Bronx Aging Study) & 2 & 11 & 1 & 0 & 0 & 0 & 0 & 0 \\
\hline 20 & $\begin{array}{l}\text { Emergence and evolution of social self-management } \\
\text { of Parkinson's disease }\end{array}$ & 2 & 2 & 1 & 1 & 0 & 4 & 0 & 0 \\
\hline 21 & $\begin{array}{l}\text { Hallucinations and sleep disorders in PD: ten-year } \\
\text { prospective longitudinal study }\end{array}$ & 2 & 1 & 1 & 0 & 1 & 0 & 0 & 0 \\
\hline 22 & Harvard Alumni Health Study & 0 & 0 & 0 & 0 & 0 & 0 & 0 & 0 \\
\hline 23 & Health Professionals Follow-up Study & 0 & 0 & 0 & 0 & 0 & 0 & 0 & 0 \\
\hline 24 & Honolulu Asia Aging Study & 2 & 4 & 2 & 0 & 1 & 0 & 1 & 1 \\
\hline 25 & $\begin{array}{l}\text { Longitudinal study of normal cognition in } \\
\text { Parkinson disease }\end{array}$ & 2 & 6 & 2 & 1 & 0 & 0 & 0 & 0 \\
\hline 26 & $\begin{array}{l}\text { Long-term outcomes of bilateral subthalamic nucleus } \\
\text { stimulation in patients with advanced Parkinson's disease }\end{array}$ & 2 & 2 & 2 & 2 & 0 & 0 & 0 & 0 \\
\hline 27 & $\begin{array}{l}\text { Loss of ability to work and ability to live independently } \\
\text { in Parkinson's disease }\end{array}$ & 2 & 0 & 1 & 1 & 0 & 0 & 0 & 0 \\
\hline 28 & $\begin{array}{l}\text { Major life events and development of major depression } \\
\text { in Parkinson's disease patients }\end{array}$ & 1 & 2 & 2 & 0 & 0 & 0 & 0 & 0 \\
\hline 29 & $\begin{array}{l}\text { Mayo Clinic cohort study of Personality and Aging } \\
\text { (including Rochester Epidemiology project) }\end{array}$ & 0 & 0 & 4 & 0 & 0 & 0 & 0 & 0 \\
\hline 30 & $\begin{array}{l}\text { Mayo clinic study of aging (Olmsted county resident) - } \\
\text { Rochester Epidemiology project indexing system }\end{array}$ & 1 & 10 & 3 & 0 & 1 & 0 & 1 & 1 \\
\hline
\end{tabular}


Table 3 Overview of data source measurements and of the number of evaluations or assessments applied ( $n=53)$ (Continued)

\begin{tabular}{|c|c|c|c|c|c|c|c|c|c|}
\hline $\mathrm{Nb}$ & Study & $\begin{array}{l}\text { Motor and } \\
\text { neurological }\end{array}$ & Cognition & Psychiatry & $\begin{array}{l}\text { Activities } \\
\text { of daily living }\end{array}$ & Sleep & $\begin{array}{l}\text { Quality } \\
\text { of life }\end{array}$ & Autonomic & Other \\
\hline 31 & Molecular Epidemiology of Parkinson's Disease & 1 & 3 & 0 & 0 & 0 & 0 & 0 & 0 \\
\hline 32 & $\begin{array}{l}\text { Mood and motor trajectories in Parkinson's disease: } \\
\text { multivariate latent growth curve modeling }\end{array}$ & 1 & 0 & 2 & 0 & 0 & 0 & 0 & 0 \\
\hline 33 & Mood and Subthalamic Nucleus Deep Brain Stimulation & 2 & 0 & 7 & 0 & 0 & 0 & 0 & 0 \\
\hline 34 & $\begin{array}{l}\text { Morris K Udall Parkinson's Disease Research Center of } \\
\text { Excellence cohort - Veteran affair }\end{array}$ & 2 & 3 & 2 & 1 & 0 & 1 & 0 & 1 \\
\hline 35 & $\begin{array}{l}\text { National Parkinson Foundation Quality } \\
\text { Improvement Initiative }\end{array}$ & 3 & 2 & 0 & 0 & 0 & 1 & 0 & 1 \\
\hline 36 & NeuroGenetics Research Consortium & 1 & 1 & 1 & 0 & 0 & 0 & 0 & 0 \\
\hline 37 & Nurses' Health Study & 0 & 5 & 0 & 0 & 0 & 0 & 0 & 0 \\
\hline 38 & Oxford Parkinson's Disease Centre & 6 & 3 & 2 & 1 & 2 & 1 & 0 & 2 \\
\hline 39 & Parkinson's Associated Risk Study & 0 & 0 & 2 & 0 & 0 & 0 & 0 & 1 \\
\hline 40 & Parkinson's Disease Biomarkers Program & 4 & 3 & 6 & 1 & 6 & 5 & 1 & 3 \\
\hline 41 & $\begin{array}{l}\text { Parkinson's Disease Research Education and Clinical } \\
\text { Center - Parkinson's Genetic Research Study }\end{array}$ & 3 & 1 & 0 & 1 & 0 & 0 & 0 & 0 \\
\hline 42 & $\begin{array}{l}\text { Parkinson's disease: increased motor network activity } \\
\text { in the absence of movement }\end{array}$ & 2 & 1 & 0 & 0 & 0 & 0 & 0 & 0 \\
\hline 43 & Parkinson's progression biomarkers initiative & 1 & 5 & 4 & 2 & 2 & 0 & 1 & 2 \\
\hline 44 & $\begin{array}{l}\text { Prospective cohort study of impulse control disorders } \\
\text { in Parkinson's disease }\end{array}$ & 2 & 1 & 2 & 1 & 0 & 0 & 0 & 0 \\
\hline 45 & $\begin{array}{l}\text { Rate of 6-18Ffluorodopa uptake decline in striatal } \\
\text { subregions in Parkinson's disease }\end{array}$ & 2 & 1 & 0 & 0 & 0 & 0 & 0 & 0 \\
\hline 46 & Religious Order Study & 6 & 11 & 4 & 1 & 0 & 0 & 0 & 0 \\
\hline 47 & Rush Memory and Aging Project & 5 & 1 & 3 & 1 & 1 & 0 & 0 & 2 \\
\hline 48 & Study of Osteoporotic Fractures (SOF) Research Group & 2 & 1 & 1 & 0 & 0 & 0 & 0 & 2 \\
\hline 49 & The effect of age of onset of PD on risk of dementia & 1 & 6 & 1 & 0 & 0 & 0 & 0 & 0 \\
\hline 50 & $\begin{array}{l}\text { University of California Los Angeles Center for Genes } \\
\text { and Environmental in Parkinson's Disease }\end{array}$ & 2 & 1 & 1 & 0 & 0 & 0 & 0 & 0 \\
\hline 51 & University of Miami Brain Endowment Bank & 1 & 0 & 0 & 1 & 0 & 0 & 0 & 2 \\
\hline 52 & $\begin{array}{l}\text { UPDRS activity of daily living score as a marker } \\
\text { of Parkinson's disease progression }\end{array}$ & 1 & 0 & 1 & 1 & 0 & 0 & 0 & 0 \\
\hline 53 & Washington Heights-Inwood Columbia Aging & 1 & 6 & 0 & 1 & 0 & 0 & 0 & 0 \\
\hline
\end{tabular}

Our study has several limitations. First of all, only one reader has conducted the record selection and the data extraction unlike systematic reviews. Nevertheless, the search methods identified a large number of PD data sources for extraction and comparison. No contact was established with investigators of the included studies to confirm data extraction results. To address this issue, a second step has been performed after the data extraction from the publications, to update and complete the published information with all other available sources. At risk/prodromal cohorts have not been separated from clinical PD cohorts, but the distinction between these two subgroups has recently been described as artificial [4].

Our study has several strengths. It is the first review of existing real world longitudinal data sources on PD in
USA to our knowledge. Moreover, it was performed with broad research criteria and without any limitation on language, type of publication or type of measurements. This review creates an integrated view and should assist investigators and clinicians to identify and optimize the measurements that best match with their objectives and the already existing data sources.

\section{Conclusion}

In conclusion, many longitudinal real world data sources on PD exist. Different types of measurements have been used over time. To allow comparison and pooling of these multiple data sources, it will be essential to harmonize practices in terms of types of measurements. 
Table 4 Measurements classification and use in data sources $(n=108)$

\begin{tabular}{|c|c|c|c|}
\hline Dimension & Measurement acronym & Measurement full name & Data sources (number and numbering) \\
\hline \multicolumn{4}{|c|}{ Motor and neurological $(n=46)$} \\
\hline \multirow[t]{3}{*}{ Global } & H\&Y & Hoehn and Yahr & $\begin{array}{l}(n=30)^{\circ} 1,2,3,4,5,7,9,10,13,14,16,17,18,20,21,25,26,27 \\
31,33,34,35,38,40,41,42,44,45,50,51\end{array}$ \\
\hline & UPDRS-III & $\begin{array}{l}\text { Unified Parkinson's Disease Rating } \\
\text { Scale - motor examination }\end{array}$ & $\begin{array}{l}(n=41)^{\circ} 1,2,3,4,5,7,8,10,11,13,14,16,17,18,19,20,21,24, \\
25,26,27,28,30,32,33,34,35,36,38,40,41,42,43,44,45,46, \\
47,49,50,52,53\end{array}$ \\
\hline & UPDRS-IV & $\begin{array}{l}\text { Unified Parkinson's Disease Rating } \\
\text { Scale - motor complications }\end{array}$ & $(n=2) n^{\circ} 1,14$ \\
\hline \multirow[t]{9}{*}{ Gait and balance } & & Berg balance test & $(n=2) n^{\circ} 7,10$ \\
\hline & & Flamingo test & $(n=1) n^{\circ} 38$ \\
\hline & $\mathrm{FGA}$ & Functional Gait Assessment & $(n=2) n^{\circ} 7,10$ \\
\hline & FOGQ & Freezing of gait questionnaire & $(n=2) n^{\circ} 7,10$ \\
\hline & & Gait speed & $(n=4) n^{\circ} 7,8,10,46$ \\
\hline & PIGD & $\begin{array}{l}\text { Postural Instability / Gait Difficulty } \\
\text { scale }\end{array}$ & $(n=2) n^{\circ} 5,40$ \\
\hline & & Tandem gait & $(n=1) n^{\circ} 48$ \\
\hline & TUG & Time Up and Go test & $(n=6) n^{\circ} 7,10,35,38,40,47$ \\
\hline & & Walk test & $(n=5) n^{\circ} 7,10,46,47,48$ \\
\hline \multirow[t]{4}{*}{ Fine movement } & & Finger tapping & $(n=3) n^{\circ} 4,46,47$ \\
\hline & & Purdue pegboard test & $(n=6) n^{\circ} 4,7,10,38,46,47$ \\
\hline & & Reaction time & $(n=1) n^{\circ} 24$ \\
\hline & & Unknown & $(n=1) \mathrm{n}^{\circ} 15$ \\
\hline \multicolumn{4}{|l|}{ Cognition $(n=41)$} \\
\hline \multirow[t]{15}{*}{ Global } & ACE & Addenbrooke's Cognitive Examination & $(n=1) n^{\circ} 40$ \\
\hline & AD-8 & Ascertian Dementia 8-item Informant & $(n=1) n^{\circ} 31$ \\
\hline & BDRS & Blessed Dementia Rating Scale & $(n=2) n^{\circ} 19,53$ \\
\hline & CAMCOG & Cambridge Cognitive Assessment & $(n=1) n^{\circ} 49$ \\
\hline & CASI & Cognitive Abilities Screening Instrument & $(n=1) n^{\circ} 24$ \\
\hline & CDR & Clinical Dementia Rating scale & $(n=5) n^{\circ} 3,4,6,19,30,53$ \\
\hline & & Clock drawing test & $(n=1) n^{\circ} 4$ \\
\hline & DRS2 & Dementia Rating Scale 2 & $(n=6) n^{\circ} 4,19,25,26,34,53$ \\
\hline & HDS & Hasegawa Dementia Rating Scale & $(n=1) n^{\circ} 24$ \\
\hline & MDRS & Mattis Dementia Rating Scale & $(n=2) n^{\circ} 4,26$ \\
\hline & MMSE & Mini Mental State Examination & $\begin{array}{l}(n=30)^{\circ} 1,3,4,5,7,9,10,11,12,14,15,16,18,20,21,24,26 \\
28,31,34,36,37,38,42,44,45,46,47,48,50\end{array}$ \\
\hline & MoCA & Montreal Cognitive Assessment & $(n=9) n^{\circ} 1,4,5,20,34,38,40,41,43$ \\
\hline & IQCODE & $\begin{array}{l}\text { Informant Questionnaire on Cognitive } \\
\text { Decline in Elderly }\end{array}$ & $(n=1) n^{\circ} 24$ \\
\hline & SPMSQ & Short Portable Mental Status Questionnaire & $(n=1) n^{\circ} 40$ \\
\hline & TICS-M & $\begin{array}{l}\text { Telephone Interview Cognitive Status } \\
\text { Modified }\end{array}$ & $(n=2) n^{0} 31,37$ \\
\hline \multirow{2}{*}{$\begin{array}{l}\text { Attention/ Working } \\
\text { memory }\end{array}$} & & Digit span & $(n=6) n^{\circ} 3,4,11,30,37,46$ \\
\hline & & STROOP test & $(n=2) n^{\circ} 4,11$ \\
\hline \multirow[t]{3}{*}{ Executive function } & & Comprehension & $(n=2) n^{\circ} 28,49$ \\
\hline & RBANS & $\begin{array}{l}\text { Repeatable Battery for Assessment of } \\
\text { Neuropsychological Status }\end{array}$ & $(n=1) n^{\circ} 8$ \\
\hline & & Symbol digit & $(n=3) n^{\circ} 16,43,46$ \\
\hline
\end{tabular}


Table 4 Measurements classification and use in data sources $(n=108)$ (Continued)

\begin{tabular}{|c|c|c|c|}
\hline Dimension & Measurement acronym & Measurement full name & Data sources (number and numbering) \\
\hline & & Trail Making Test & $(n=4) n^{\circ} 3,4,19,30$ \\
\hline & & Verbal fluency & $(n=12) n^{\circ} 3,9,11,19,25,30,35,37,38,43,46,49$ \\
\hline \multirow[t]{6}{*}{ Language } & BNT & Boston Naming Test & $(n=5) n^{\circ} 3,25,30,37,46$ \\
\hline & COWA & Controlled Oral Word Association & $(n=4) n^{\circ} 1,3,4,11$ \\
\hline & FAS & $\begin{array}{l}\text { Letter-Number Sequencing and Phonemic } \\
\text { verbal fluency }\end{array}$ & $(n=2) n^{\circ} 11,25$ \\
\hline & & Naming & $(n=1) n^{\circ} 49$ \\
\hline & NART & American National Adult Reading test & $(n=2) n^{\circ} 3,46$ \\
\hline & WAIS & Wechlser Adult Intelligence Scale & $(n=6) n^{\circ} 3,4,9,11,19,30$ \\
\hline \multirow[t]{8}{*}{ Memory } & BIMC & Blessed Information Memory Concentration & $(n=2) n^{\circ} 6,19$ \\
\hline & FCSRT & Free and Cue Selective Reminding Test & $(n=2) n^{\circ} 3,19$ \\
\hline & FOME & Fuld Object Memory Evaluation & $(n=1) n^{0} 19$ \\
\hline & HVLT & Hopkins Verbal Learning test & $(n=3) n^{\circ} 11,25,43$ \\
\hline & & Memory & $(n=5) n^{\circ} 3,16,35,46,53$ \\
\hline & RAVLT & Rey auditory verbal learning test & $(n=3) n^{\circ} 1,4,30$ \\
\hline & & Recall & $(n=2) n^{\circ} 46,49$ \\
\hline & WMS & Wechsler Memory Scale & $(n=2) n^{\circ} 9,30$ \\
\hline \multirow[t]{8}{*}{ Visual-spatial } & BVRT & Benton Visual Retention Test & $(n=1) n^{\circ} 9$ \\
\hline & CPM & Raven's coloured progressive matrices & $(n=2) \mathrm{n}^{\circ} 19,46$ \\
\hline & JLO & Benton Judgement Line Orientation & $(n=4) n^{\circ} 4,25,43,46$ \\
\hline & & Orientation & $(n=1) n^{\circ} 53$ \\
\hline & PARR & Picture Arrangement subtest & $(n=1) n^{\circ} 9$ \\
\hline & ROCF & $\begin{array}{l}\text { Rey-Osterrieth Complex Figure test } \\
\text { recall }\end{array}$ & $(n=1) n^{\circ} 11$ \\
\hline & & Visual attention & $(n=1) n^{0} 19$ \\
\hline & & Unknown & $(n=1) n^{0} 15$ \\
\hline \multicolumn{4}{|c|}{ Psychiatric symptoms $(n=38)$} \\
\hline \multirow[t]{12}{*}{ Depression / Anxiety } & AS & Apathy Evaluation Scale & $(n=3) n^{\circ} 4,32,33$ \\
\hline & $\mathrm{BAl}$ & Beck Anxiety Inventory & $(n=4) n^{\circ} 18,30,33,44$ \\
\hline & $\mathrm{BDI}$ & Beck Depression Inventory & $(n=9) n^{\circ} 5,11,18,26,30,32,33,36,44$ \\
\hline & CESD-10 & $\begin{array}{l}\text { Center for Epidemiological Studies } \\
\text { Depression Scale }\end{array}$ & $(n=3) n^{\circ} 24,39,47$ \\
\hline & GDS & Geriatric Depression Screening scale & $(n=17) n^{\circ} 1,3,4,5,7,8,10,14,20,25,26,28,34,40,43,48,50$ \\
\hline & HAM-A & Hamilton Anxiety Rating Scale & $(n=2) n^{\circ} 33,40$ \\
\hline & HDRS & Hamilton Depression Rating Scale & $(n=3) n^{\circ} 4,15,33$ \\
\hline & Leeds & Leeds anxiety and depression scale & $(n=1) n^{\circ} 38$ \\
\hline & SCID & Structured Clinical Interview - Depression & $(n=2) n^{\circ} 28,40$ \\
\hline & STAl & State Trait Anxiety Inventory & $(n=4) n^{\circ} 18,24,39,43$ \\
\hline & UPDRS-I & $\begin{array}{l}\text { Unified Parkinson's Disease Rating S } \\
\text { cale - mentation behavior and mood }\end{array}$ & $(n=7) n^{\circ} 1,14,17,25,27,43,52$ \\
\hline & ZUNG & Zung depression scale & $(n=1) n^{0} 19$ \\
\hline \multirow[t]{3}{*}{ TOC } & OCl-R & Obsessive-Compulsive Inventory - Revised & $(n=1) n^{\circ} 18$ \\
\hline & QUIP & $\begin{array}{l}\text { Questionnaire for impulsive-compulsive } \\
\text { disorders in parkinson's disease-rating } \\
\text { scale }\end{array}$ & $(n=2) n^{\circ} 40,43$ \\
\hline & YBOCS & Yale-Brown obsessive-compulsive scale & $(n=1) n^{\circ} 33$ \\
\hline
\end{tabular}


Table 4 Measurements classification and use in data sources $(n=108)$ (Continued)

\begin{tabular}{|c|c|c|c|}
\hline Dimension & Measurement acronym & Measurement full name & Data sources (number and numbering) \\
\hline \multirow[t]{8}{*}{ Other } & CoNeg & composite negative score & $(n=1) n^{\circ} 29$ \\
\hline & MMPI & Multiphasic Personality Inventory & $(n=1) n^{\circ} 29$ \\
\hline & NPI & NeuroPsychiatric Inventory questionnaire & $(n=3) n^{\circ} 1,34,47$ \\
\hline & QABB & Questionnaire About Buying Behaviour & $(n=1) n^{\circ} 40$ \\
\hline & Rush & Rush Hallucination Inventory & $(n=1) n^{\circ} 21$ \\
\hline & SCS & Sexual Compulsivity Scale & $(n=1) n^{\circ} 40$ \\
\hline & YMRS & Young Mania Rating Scale & $(n=1) n^{\circ} 33$ \\
\hline & & Unknown & $(n=4) n^{\circ} 6,15,46,49$ \\
\hline \multicolumn{4}{|c|}{ Activities of daily living $(n=22)$} \\
\hline & ACS & Activity Card Sort & $(n=1) n^{\circ} 20$ \\
\hline & ADCS-ADL & $\begin{array}{l}\text { Alzheimer's Disease Cooperative Study } \\
\text { ADL Inventory }\end{array}$ & $(n=1) n^{\circ} 25$ \\
\hline & IADL & Katz Instrumental Activity of Daily Living & $(n=2) n^{\circ} 46,47$ \\
\hline & S\&E & $\begin{array}{l}\text { Schwab \& England activities of daily } \\
\text { living scale }\end{array}$ & $(n=10) n^{\circ} 5,14,18,26,34,38,41,43,44,53$ \\
\hline & UPDRS-\| & $\begin{array}{l}\text { Unified Parkinson's Disease Rating Scale - } \\
\text { self-evaluation of the activities of daily } \\
\text { living }\end{array}$ & $(n=9) n^{\circ} 1,5,11,14,26,27,40,43,52$ \\
\hline & & Unknown & $(n=3) n^{\circ} 15,17,51$ \\
\hline \multicolumn{4}{|c|}{ Sleep quality $(n=11)$} \\
\hline & & Actigraphy & $(n=1) n^{\circ} 47$ \\
\hline & ESS & Epworth Sleepiness Scale & $(n=4) n^{\circ} 5,14,38,43$ \\
\hline & FSS & Fatigue Severity Scale & $(n=1) n^{\circ} 40$ \\
\hline & $|S|$ & Insomnia Severity Index & $(n=1) n^{\circ} 40$ \\
\hline & MSQ & Mayo clinic Sleep Questionnaire & $(n=2) n^{\circ} 4,30$ \\
\hline & PDSS & Parkinson's disease sleep scale & $(n=1) n^{\circ} 40$ \\
\hline & PSQI & Pittsburg Sleep Quality Index & $(n=2) n^{\circ} 21,40$ \\
\hline & RBDSQ & $\begin{array}{l}\text { REM Sleep Behaviour Disorder Screening } \\
\text { Questionnaire }\end{array}$ & $(n=2) n^{\circ} 38,43$ \\
\hline & SA-SDQ & $\begin{array}{l}\text { Sleep Apnea Scale of Sleep Disorders } \\
\text { Questionnaire }\end{array}$ & $(n=1) n^{\circ} 40$ \\
\hline & SSS & Stanford Sleepiness Scale & $(n=1) n^{\circ} 40$ \\
\hline & & Unknown & $(n=2) n^{\circ} 15,24$ \\
\hline \multicolumn{4}{|c|}{ Quality of life $(n=9)$} \\
\hline & EQ-5D & $\begin{array}{l}\text { Euro Quality of Life } 5 \text { Dimension } \\
\text { questionnaire }\end{array}$ & $(n=2) n^{\circ} 14,38$ \\
\hline & Neuro-QOL & Quality of Life in Neurological Disorders & $(n=1) n^{\circ} 34$ \\
\hline & $\mathrm{NHP}$ & Nottingham Health Profile & $(n=1) n^{0} 20$ \\
\hline & PDQUALIF & Parkinson's Disease Quality of Life Scale & $(n=3) n^{\circ} 14,18,40$ \\
\hline & PDQ-39 & 39-item Parkinson's disease quality of life & $(n=5) n^{\circ} 7,10,20,35,40$ \\
\hline & PIMS & Parkinson's Impact Scale & $(n=1) n^{\circ} 40$ \\
\hline & SF-12 & The 12 item Short Form health survey & $(n=2) n^{\circ} 14,20$ \\
\hline & SF-36 & The 36 item Short Form health survey & $(n=1) n^{\circ} 40$ \\
\hline & SWAL-QOL & Swallow-specific quality of life & $(n=1) n^{\circ} 40$ \\
\hline \multicolumn{4}{|c|}{ Autonomic symptoms $(n=7)$} \\
\hline & & Bowel movement & $(n=1) n^{\circ} 24$ \\
\hline & COMPASS & Composite autonomic symptom Scale & $(n=1) n^{\circ} 40$ \\
\hline
\end{tabular}


Table 4 Measurements classification and use in data sources $(n=108)$ (Continued)

\begin{tabular}{|c|c|c|c|}
\hline Dimension & Measurement acronym & Measurement full name & Data sources (number and numbering) \\
\hline & SCOPA-AUT & $\begin{array}{l}\text { Scales for outcomes of Parkinson's } \\
\text { Disease - autonomic symptoms }\end{array}$ & $(n=3) n^{\circ} 4,5,43$ \\
\hline & & Unknown & $(n=2) n^{\circ} 15,30$ \\
\hline \multicolumn{4}{|l|}{ Other $(n=20)$} \\
\hline \multirow[t]{3}{*}{ Olfaction } & Brief-SIT & Brief Smell Identification Test & $(n=2) n^{\circ} 24,47$ \\
\hline & & $\begin{array}{l}\text { 16-item sniffin' Sticks Odour Identification } \\
\text { test }\end{array}$ & $(n=1) n^{\circ} 38$ \\
\hline & UPSIT & $\begin{array}{l}\text { University of Pennsylvania Smell } \\
\text { Identification Test }\end{array}$ & $(n=6) n^{\circ} 1,4,5,34,39,43$ \\
\hline \multirow[t]{2}{*}{ Restless legs syndrome } & $\mathrm{CH}-\mathrm{RLSQ}$ & $\begin{array}{l}\text { Cambridge-Hopkins Restless Legs } \\
\text { Syndrome Diagnostic Questionnaire }\end{array}$ & $(n=1) n^{\circ} 40$ \\
\hline & IRLSSG & $\begin{array}{l}\text { Instrument for the Assessment of } \\
\text { Restless Legs Syndrome Severity }\end{array}$ & $(n=1) n^{\circ} 4$ \\
\hline \multirow[t]{4}{*}{ Caregiver } & $\mathrm{CSI}$ & caregiver strain index & $(n=1) n^{\circ} 35$ \\
\hline & & deJong-Gierveld Loneliness Scale & $(n=1) n^{\circ} 47$ \\
\hline & MCSI & Multidimensional Caregiver Strain Index & $(n=1) n^{\circ} 35$ \\
\hline & & Caregiver interview & $(n=1) n^{\circ} 21$ \\
\hline \multirow[t]{16}{*}{ Other } & & Agonal state questionnaire & $(n=1) n^{\circ} 51$ \\
\hline & $C G l$ & Clinical Global Impression scale & $(n=1) n^{\circ} 38$ \\
\hline & CIRS & Chronic Illness Resource Survey & $(n=1) n^{\circ} 20$ \\
\hline & GHS & Global Health Score & $(n=1) n^{\circ} 8$ \\
\hline & GIS & Global Impression Scale & $(n=1) n^{\circ} 51$ \\
\hline & & Howard-Dohlman device & $(n=1) n^{\circ} 48$ \\
\hline & MNA & Mini Nutritional Assessment & $(n=1) n^{\circ} 40$ \\
\hline & MOS & Medical outcome study & $(n=1) n^{\circ} 20$ \\
\hline & MSSSS & $\begin{array}{l}\text { Medical Outcomes Study Social Support } \\
\text { Scale }\end{array}$ & $(n=1) n^{\circ} 28$ \\
\hline & & Pain & $(n=1) n^{\circ} 40$ \\
\hline & PASE & Physical Activity Scale for the Elderly & $(n=3) n^{\circ} 7,10,43$ \\
\hline & SRRS & Social Readjustment Rating scale & $(n=1) n^{\circ} 28$ \\
\hline & $\mathrm{SSCl}$ & Stigma Scale for Chronic Illness & $(n=1) n^{\circ} 20$ \\
\hline & & Tremor rating & $(n=1) n^{\circ} 4$ \\
\hline & & Visual acuity & $(n=1) n^{\circ} 48$ \\
\hline & & Unknown & $(n=1) n^{\circ} 15$ \\
\hline
\end{tabular}

\section{Appendix 1}

Search strategy.

Equation 1: Disease selection

(EMB.EXACT("Parkinson disease") OR MESH.EXACT(“Parkinson Disease") OR ab("Parkinson"”)

OR ti("Parkinson"”) OR EMB.EXACT("antiparkinson agent") OR MESH.EXACT(“Antiparkinson Agents")) AND (human(yes) AND human(yes)).

Equation 2: Disease exclusion

(MESH.EXACT("Parkinson Disease, Postencephalitic") OR MESH.EXACT("Parkinson Disease, Secondary") OR EMB.EXACT("Wolff Parkinson White syndrome") OR EMB.EXACT("experimental parkinsonism") OR EMB.EXACT(“parkinsonism”) OR EMB.EXACT("MPTPinduced parkinsonism")) AND (human(yes) AND human(yes))

Equation 3: Study type selection

((EMB.EXACT("register") OR EMB.EXACT("long term care") OR EMB.EXACT("retrospective study") OR EMB.EXACT("prospective study") OR EMB.EXACT("cohort analysis") OR EMB.EXACT("clinical practice") OR EMB.EXACT("longitudinal study")) OR (MESH.EXACT(“Cohort Studies") OR MESH.EXACT("Registries") OR MESH.EXACT("Longitudinal Studies") OR MESH.EXACT(“Long-Term Care") OR MESH.EXACT ("Retrospective Studies") OR MESH.EXACT(“Prospective Studies”) OR 
MESH.EXACT(“Practice Patterns, Physicians"))) OR (((longitudinal OR retrospective OR prospective OR cohort OR "follow up" OR observational OR naturalistic OR "cross"sectional" OR epidemio* OR database) NEAR/1 (study OR studies)) OR "cohort analysis" OR "registry" OR "register" OR "real-world" OR "treatment pattern" OR "survey" OR "medical records" OR "population-correlation" OR "population-based" OR "population-level")

Equation 4: Study type exclusion

((MESH.EXACT(“Case-Control Studies”) OR MESH.EXACT(“Controlled Before-After Studies”) OR.

MESH.EXACT(“Feasibility Studies") OR MESH.EXACT(“Clinical Trial”) OR MESH.EXACT(“Organizational Case Studies") OR MESH.EXACT(“Evaluation Studies")) OR (EMB.EXACT ("major clinical study") OR EMB.EXACT("in vivo study") OR EMB.EXACT("evaluation study") OR EMB.EXACT("in vitro study") OR EMB.EXACT("first in human study") OR EMB.EXACT("experimental study") OR EMB.EXACT("case study") OR EMB.EXACT("clinical study") OR EMB.EXACT("intervention study") OR EMB.EXACT(“case control study”))).

Equation 5: Combination of the previous equation (Equation 1 NOT Eq. 2) AND (Eq. 3 NOT Eq. 4)

Equation 6: Country selection

GI("United States"”) OR ti("America") OR ab("America *") OR ab("usa") OR ti(“usa") OR ab("us") OR ti(“us") OR ab("u.s") OR ti("u.s").

Equation 7: Application of the combination equation to the country of interest

Equation 6 AND Eq. 6

\section{Appendix 2}

List of outcomes extracted.

Acronym

oFull name

oCountry (-ies)

$\circ$ Database size (total number of patients and number of Parkinsonian patients)

oDatabase type

oName of investigator (corresponding author of the publication, reference person)

oFunder(s)

oMedical imaging

oScales list

oScales dimension 1: Activities of daily living

oScales dimension 2: Cognition

oScales dimension 3: Motor or neurologic symptoms

oScales dimension 4: Psychiatric symptoms

oScales dimension 5: Sleep quality

oScales dimension 6: Quality of life

oScales dimension 7: Autonomic symptoms

oScales dimension 8: Other

oHealthcare costs

oGenetics
○Comorbidities

-Current medications

oSeverity of disease

- Caregiver burden

oDate of beginning of the study

$\circ$ Date of end of the study

oDuration of follow-up

-Planned follow-ups

oParticular inclusion criteria

\section{Abbreviations}

BDI: Beck Depression Inventory; ESS: Epworth Sleepiness Scale; FDA: Food and Drug Administration; GDS: Geriatric Depression Scale; H\&Y: Hoehn and Yahr scale; MMSE: Mini Mental State Examination; PD: Parkinson's disease; PDQ-39: 39-item Parkinson's disease Quality of life; S\&E: Schwab and England; SCOPA-AUT: autonomic part of the Scales for outcomes of Parkinson's disease; UPDRS-III: Unified Parkinson's Disease Rating Scale part III;

USA: United States of America

\section{Acknowledgements}

Highly appreciated is also the support of Sandrine Thoreau for assisting with the search strategy.

\section{Funding}

The study was funded by Lundbeck SAS. The funding source, beyond the employees involved as authors, did not participate in the design of the study; collection, analysis nor interpretation of the data; nor the writing of the manuscript.

\section{Availability of data and materials}

Not applicable.

\section{Authors' contributions}

AT: Research project execution, statistical analysis execution, manuscript writing, review and critique. LJ: Research project conception and organization, statistical analysis review and critique, manuscript review and critique. LI: Research project conception and organization, statistical analysis review and critique, manuscript review and critique. All authors read and approved the final manuscript

Ethics approval and consent to participate

Not applicable.

Consent for publication

Not applicable.

\section{Competing interests}

$\mathrm{L}$ is a current employee and AT was a resident in Lundbeck SAS and LI was an employee of Lundbeck SAS at the time the research was carried out.

\section{Publisher's Note}

Springer Nature remains neutral with regard to jurisdictional claims in published maps and institutional affiliations.

Received: 16 February 2017 Accepted: 22 November 2017

Published online: 08 December 2017

\section{References}

1. Kowal SL, Dall TM, Chakrabarti R, Storm MV, Jain A. The current and projected economic burden of Parkinson's disease in the United States. Mov Disord. 2013:28:311-8

2. Use of Real-World Evidence to Support Regulatory Decision-Making for Medical Devices: FDA Draft Guidance for Industry and Staff. Food Drug Administration. http://www.fda.gov/ucm/groups/fdagov-public/@fdagovmeddev-gen/documents/document/ucm513027.pdf. Accessed 29 Nov 2017.

3. Bot BM, Suver C, Neto EC, et al. The mPower study, Parkinson disease mobile data collected using ResearchKit. Scientific Data. 2016;3:160011. doi: 10.1038/sdata.2016.11. 
4. Lerche S, Liepelt-Scarfone I, Alves G, et al. Methods in Neuroepidemiology characterization of European longitudinal cohort studies in Parkinson's disease - report of the JPND working group BioLoc-PD. Neuroepidemiology. 2015;45:282-97.

5. Mahajan R. Real world data: additional source for making clinical decisions. Int J Appl Basic Med Res. 2015; doi:10.4103/2229-516X.157148.

6. Annemans $L$, Aristides $M$, Kubin M. Real life data: a growing need. ISPOR Connections. http://www.ispor.org/news/articles/oct07/rld.asp. Accessed 29 Nov 2017.

7. Shulman LM, Armstrong M, Ellis T, et al. Disability rating scales in Parkinson's disease: critique and recommendations. Mov Disord. 2016;31:1455-65.

8. Doty RL. Olfaction in Parkinson's disease and related disorders. Neurobiol Dis. 2012:46:527-52.

9. Ravina B, Tanner C, Dieuliis D, et al. A longitudinal program for biomarker development in Parkinson's disease: a feasibility study. Mov Disord. 2009; 24(14):2081-90.

10. Tang CC, Poston $\mathrm{KL}$, Dhawan $\mathrm{V}$, et al. Abnormalities in metabolic network activity precede the onset of motor symptoms in Parkinson's disease. J Neurosci. 2010;30(3):1049-56.

11. Gomperts SN, Locascio JJ, Rentz D, et al. Amyloid is linked to cognitive decline in patients with Parkinson disease without dementia. Neurology. 2013;80(1):85-91.

12. Caviness JN, Hentz JG, Belden CM, et al. Longitudinal EEG changes correlate with cognitive measure deterioration in Parkinson's disease. J Parkinsons Dis. 2015;5(1):117-24

13. Alcalay RN, Mirelman A, Saunders-Pullman R, et al. Parkinson disease phenotype in Ashkenazi Jews with and without LRRK2 G2019S mutations. Mov Disord. 2013;28(14):1966-71.

14. O'Brien RJ, Resnick SM, Zonderman AB, et al. Neuropathologic studies of the Baltimore longitudinal study of aging (BLSA). J Alzheimers Dis. 2009;18(3): 665-75

15. Duncan RP, Leddy AL, Cavanaugh JT, et al. Detecting and predicting balance decline in Parkinson disease: a prospective cohort study. J Parkinsons Dis. 2015;5(1):131-9.

16. Mahoney JR, Verghese J, Holtzer R, et al. The evolution of mild parkinsonian signs in aging. J Neurol. 2014;261(10):1922-8.

17. Bohnen NI, Koeppe RA, Minoshima S, et al. Cerebral glucose metabolic features of Parkinson disease and incident dementia: longitudinal study. J Nucl Med. 2011;52(6):848-55.

18. Dibble LE, Cavanaugh JT, Earhart GM, et al. Charting the progression of disability in Parkinson disease: study protocol for a prospective longitudinal cohort study. BMC Neurol. 2010;10:110.

19. O'Suilleabhain PE, Oberle R, Bartis C, et al. Clinical course in Parkinson's disease with elevated homocysteine. Parkinsonism Relat Disord. 2006;12(2):103-7.

20. Evatt ML, Delong MR, Khazai N, et al. Prevalence of vitamin d insufficiency in patients with Parkinson disease and Alzheimer disease. Arch Neurol. 2008; 65(10):1348-52.

21. Duncan RP, Leddy AL, Cavanaugh JT, et al. Comparative utility of the BESTest, mini-BESTest, and brief-BESTest for predicting falls in individuals with Parkinson disease: a cohort study. Phys Ther. 2013;93(4):542-50.

22. Holloway R, Marek K, Biglan K, et al. Long-term effect of initiating pramipexole vs levodopa in early Parkinson disease. Arch Neurol. 2009;66(5):563-70.

23. Golbe LI, Di lorio G, Sanges G, et al. Clinical genetic analysis of Parkinson's disease in the Contursi kindred. Ann Neurol. 1996;40(5):767-75.

24. Liu C, Cholerton B, Shi M, et al. CSF tau and tau/Aß42 predict cognitive decline in Parkinson's disease. Parkinsonism Relat Disord. 2015;21(3):271-6.

25. Jasinska-Myga B, Putzke JD, Wider C, et al. Depression in Parkinson's disease. Can J Neurol Sci. 2010;37(1):61-6.

26. Rabinak CA, Nirenberg MJ. Dopamine agonist withdrawal syndrome in Parkinson disease. Arch Neurol. 2010;67(1):58-63.

27. San Luciano M, Lipton RB, Wang C, et al. Clinical expression of LRRK2 G2019S mutations in the elderly. Mov Disord. 2010;25(15):2571-6.

28. Tickle-Degnen L, Saint-Hilaire M, Thomas CA, et al. Emergence and evolution of social self-management of Parkinson's disease: study protocol for a 3-year prospective cohort study. BMC Neurol. 2014;14:95

29. Goetz CG, Ouyang B, Negron A, et al. Hallucinations and sleep disorders in PD: ten-year prospective longitudinal study. Neurology. 2010;75(20):1773-9.

30. Logroscino G, Sesso HD, Paffenbarger RS Jr, et al. Physical activity and risk of Parkinson's disease: a prospective cohort study. J Neurol Neurosurg Psychiatry. 2006;77(12):1318-22.
31. Chen H, Zhang SM, Schwarzschild MA, et al. Survival of Parkinson's disease patients in a large prospective cohort of male health professionals. Mov Disord. 2006;21(7):1002-7.

32. Wong KT, Grove JS, Grandinetti A, et al. Association of fibrinogen with Parkinson disease in elderly Japanese-American men: a prospective study. Neuroepidemiology. 2010;34(1):50-4.

33. Pigott K, Rick J, Xie SX, et al. Longitudinal study of normal cognition in Parkinson disease. Neurology. 2015;85(15):1276-82.

34. Liang GS, Chou KL, Baltuch GH, et al. Long-term outcomes of bilateral subthalamic nucleus stimulation in patients with advanced Parkinson's disease. Stereotact Funct Neurosurg. 2006;84(5-6):221-7.

35. Jasinska-Myga B, Heckman MG, Wider C, et al. Loss of ability to work and ability to live independently in Parkinson's disease. Parkinsonism Relat Disord. 2012;18(2):130-5

36. Rod NH, Bordelon $\mathrm{Y}$, Thompson A, et al. Major life events and development of major depression in Parkinson's disease patients. Eur J Neurol. 2013;20(4):663-70.

37. Bower JH, Grossardt BR, Maraganore DM, et al. Anxious personality predicts an increased risk of Parkinson's disease. Mov Disord. 2010;25(13):2105-13.

38. Roberts RO, Geda YE, Knopman DS, et al. The Mayo Clinic study of aging: design and sampling, participation, baseline measures and sample characteristics. Neuroepidemiology. 2008;30(1):58-69.

39. Markopoulou K, Biernacka JM, Armasu SM, et al. Does a-synuclein have a dual and opposing effect in preclinical vs. clinical Parkinson's disease? Parkinsonism Relat Disord. 2014;20(6):584-9.

40. Zahodne LB, Marsiske M, Okun MS, et al. Mood and motor trajectories in Parkinson's disease: multivariate latent growth curve modeling. Neuropsychology. 2012;26(1):71-80

41. Okun MS, Wu SS, Fayad S, et al. Acute and chronic mood and apathy outcomes from a randomized study of unilateral STN and GPi DBS. PLoS One. 2014;9(12):e114140.

42. Cholerton BA, Zabetian CP, Quinn JF, et al. Pacific Northwest Udall center of excellence clinical consortium: study design and baseline cohort characteristics. J Parkinsons Dis. 2013;3(2):205-14.

43. Okun MS, Siderowf A, Nutt JG, et al. Piloting the NPF data-driven quality improvement initiative. Parkinsonism Relat Disord. 2010;16(8):517-21.

44. Kay DM, Zabetian CP, Factor SA, et al. Parkinson's disease and LRRK2: frequency of a common mutation in U.S. movement disorder clinics. Mov Disord. 2006;21(4):519-23.

45. Chen $H$, Schernhammer E, Schwarzschild MA, et al. A prospective study of night shift work, sleep duration, and risk of Parkinson's disease. Am J Epidemiol. 2006;163(8):726-30.

46. Szewczyk-Krolikowski K, Menke RA, Rolinski M, et al. Functional connectivity in the basal ganglia network differentiates PD patients from controls. Neurology. 2014;83(3):208-14.

47. Qiang JK, Wong YC, Siderowf A, et al. Plasma apolipoprotein A1 as a biomarker for Parkinson disease. Ann Neurol. 2013;74(1):119-27.

48. Ofori E, Pasternak O, Planetta PJ, et al. Increased free water in the substantia nigra of Parkinson's disease: a single-site and multi-site study. Neurobiol Aging. 2015;36(2):1097-104.

49. Swanson CR, Li K, Unger TL, et al. Lower plasma apolipoprotein A1 levels are found in Parkinson's disease and associate with apolipoprotein A1 genotype. Mov Disord. 2015;30(6):805-12.

50. $\mathrm{Ko} \mathrm{JH}$, Mure H, Tang CC, et al. Parkinson's disease: increased motor network activity in the absence of movement. J Neurosci. 2013;33(10):4540-9.

51. Chahine LM, Xie SX, Simuni T, et al. Longitudinal changes in cognition in early Parkinson's disease patients with REM sleep behavior disorder. Parkinsonism Relat Disord. 2016;27:102-6.

52. Bastiaens J, Dorfman BJ, Christos PJ, et al. Prospective cohort study of impulse control disorders in Parkinson's disease. Mov Disord. 2013;28(3):327-33.

53. Gallagher CL, Oakes TR, Johnson SC, et al. Rate of 6-[18F]fluorodopa uptake decline in striatal subregions in Parkinson's disease. Mov Disord. 2011;26(4):614-20.

54. Bennett DA, Schneider JA, Arvanitakis Z, et al. Overview and findings from the religious orders study. Curr Alzheimer Res. 2012;9(6):628-45

55. Bennett DA, Schneider JA, Buchman AS, et al. Overview and findings from the rush memory and aging project. Curr Alzheimer Res. 2012;9(6): 646-63.

56. Schneider JL, Fink HA, Ewing SK, et al. The association of Parkinson's disease with bone mineral density and fracture in older women. Osteoporos Int. 2008;19(7):1093-7. 
57. Aarsland D, Kvaløy JT, Andersen K, et al. The effect of age of onset of PD on risk of dementia. J Neurol. 2007;254(1):38-45.

58. Ritz B, Rhodes SL, Bordelon Y, et al. a-Synuclein genetic variants predict faster motor symptom progression in idiopathic Parkinson disease. PLoS One. 2012;7(5):e36199.

59. Papapetropoulos S, Mash DC. Motor fluctuations and dyskinesias in advanced/end stage Parkinson's disease: a study from a population of brain donors. J Neural Transm (Vienna). 2007;114(3):341-5.

60. Harrison MB, Wylie SA, Frysinger RC, et al. UPDRS activity of daily living score as a marker of Parkinson's disease progression. Mov Disord. 2009; 24(2):224-30.

61. Louis ED, Tang MX, Schupf N. Mild parkinsonian signs are associated with increased risk of dementia in a prospective, population-based study of elders. Mov Disord. 2010;25(2):172-8.

62. Marras C, Chaudhuri KR. Nonmotor features of Parkinson's disease subtypes. Mov Disord. 2016;31(8):1095-102.

63. Garrison LP Jr, Neumann PJ, Erickson P, Marshall D, Mullins CD. Using realworld data for coverage and payment decisions: the ISPOR real-world data task force report. Value Health. 2007;10(5):326-35.

64. Litvan I, Goldman JG, Tröster Al, et al. Diagnostic criteria for mild cognitive impairment in Parkinson's disease: Movement Disorder Society task force guidelines. Mov Disord. 2012;27(3):349-56.

65. De Virgilio A, Greco A, Fabbrini G, et al. Parkinson's disease: autoimmunity and neuroinflammation. Autoimmun Rev. 2016;15(10):1005-11.

66. Sagna A, Gallo JJ, Pontone GM. Systematic review of factors associated with depression and anxiety disorders among older adults with Parkinson's disease. Parkinsonism Relat Disord. 2014;20(7):708-15. doi:10.1016/j. parkreldis.2014.03.020.

67. Martinez-Martin P, Leentjens AF, de Pedro-Cuesta J, Chaudhuri KR, Schrag AE, Weintraub D. Accuracy of screening instruments for detection of neuropsychiatric syndromes in Parkinson's disease. Mov Disord. 2016;31(3):270-9.

68. Zea-Sevilla MA, Martinez-Martin P. Rating scales and questionnaires for assessment of sleep disorders in Parkinson's disease: what they inform about? J Neural Transm. 2014;121:33. doi:10.1007/s00702-014-1217-z.

69. Martinez-Martin P, Jeukens-Visser M, Lyons KE, et al. Health-related qualityof-life scales in Parkinson's disease: critique and recommendations. Mov Disord. 2011;26(13):2371-80.

70. Goodarzi Z, Mrklas KJ, Roberts DJ, Jette N, Pringsheim T, Holroyd-Leduc J. Detecting depression in Parkinson disease: a systematic review and metaanalysis. Neurology. 2016;87(4):426-37.

71. Engler K, Lessard D, Lebouché B. A review of HIV-specific patient-reported outcome measures. Patient. 2016; doi:10.1007/s40271-016-0195-7.

72. Goldman J, Weintraub D. Advances in the treatment of cognitive impairment in Parkinson's disease. Mov Disord. 2015;30(11):1471-89.

73. Wallings R, Manzoni C, Bandopadhyay R. Cellular processes associated with LRRK2 function and dysfunction. FEBS J. 2015;282(15):2806-26.

74. Boland D, Stacy M. The economic and quality of life burden associated with Parkinson's disease: a focus on symptoms. Am J Manag Care. 2012:18(7):S168-75.

75. Noyes K, Liu H, Temkin-Greener H. Cost of caring for Medicare beneficiaries with Parkinson's disease: impact of the CMS-HCC risk-adjustment model. Dis Manag. 2006;9(6):339-48,

\section{Submit your next manuscript to BioMed Central and we will help you at every step:}

- We accept pre-submission inquiries

- Our selector tool helps you to find the most relevant journal

- We provide round the clock customer support

- Convenient online submission

- Thorough peer review

- Inclusion in PubMed and all major indexing services

- Maximum visibility for your research

Submit your manuscript at www.biomedcentral.com/submit 